\title{
The Post-Oedipal Father and The Master Builder
}

\section{Magdalen Wing-chi Ki}

Instead of focusing on Henrik Ibsen's deployment of symbols and Scandinavian folklore in The Master Builder, ${ }^{1}$ this essay argues that the play foregrounds the rise and fall of the post-oedipal father. If Theodor Adorno and Max Horkheimer relate the rise of the enlightened father to the dialectic of myth and reason, Ibsen problematizes the fall of the post-oedipal father due to the dialectic of the Imaginary troll-self, the Symbolic discourse of reason, and the Real symptom of (self-)love. In turn, The Master Builder unveils the clash between the old and new fathers, and reveals how the new father engages fresh with myths and reason, only to unleash a symptomatic force in the drive that welcomes aberrational self-destruction. Solness becomes a troll-man, and his decision strongly influences others' lives, for the living-dead wife, the performative fiancée, and the bird-woman can no longer anchor themselves in the past, or in any rational discourse that guarantees stable identities or social values. Eventually, all these characters are left to "enjoy" their symptoms. When asked to comment on the play, Ibsen refused to depreciate his characters; instead he asked, "was it so mad" for a person to undertake an action that cost "him his life, if he did it for his own happiness and only then, for the first time, achieved it?"2 The Master Builder demonstrates Ibsen's new understanding of humanity, for happiness no longer implies the pursuit of mythic ideals or reason, but a stubborn attachment to the symptom in the drive.

This essay employs a psychoanalytic (Lacanian, Žižekian) framework to map out the development of the post-oedipal father, juxtaposing Solness's subjectpositions with his changing architectural styles. I argue that, in the final stage, the master builder is keen on subverting the conventional "space-architecture" and promoting an imaginary "place-architecture." Gaston Bachelard first uses psychological vocabulary to study the "topoanalysis of the places." Following Bachelard, Edward Casey foregrounds the "placiality of the unconscious," and the psychological depth of the non-physical "imaginational place." Just as traditional space purports to avoid the void, Solness finally welcomes the empty space. His imagined castle helps redefine the concept of inhabitation, for, in the words of Casey, "inhabitation is a matter of memorably contented dwelling, of being-well

\footnotetext{
Magdalen Wing-chi Ki is Assistant Professor in the Department of English at the Hong Kong Baptist University. She received her Ph.D. in English Literature from the University of Edinburgh, specializing in Jane Austen studies. Her recent publications include: "Structure and Anti-Structure: Virginia Woolf's Feminist Politics and 'The Mark on the Wall," English Studies (2010); "Diabolical Evil and Poe's 'The Black Cat," Mississippi Quarterly (2009); "Othello and the Master-Servant Dialectic," The Dalhousie Review (2009); "Ego-Evil and 'The Tell-Tale Heart,"' Renascence (2008); "Gift Theory and the Book of Job," Theological Studies (2006); "The S(ub)lime Symptom and O'Neill's Long Day's Journey into Night" Journal of Dramatic Theory and Criticism (2006).
} 
and well-being. ${ }^{3}$

Before we go any further, a short summary of The Master Builder will reveal why post-oedipality is a key issue in this play. Solness yearns for the death of the "old" architecture so that his new design can flourish. He summons supernatural helpers and servers, and the burning down of Aline's old house makes his dream come true. Solness's modern architectural style enjoys great success, resulting in his former boss, Knut Brovik, having to work for him. For the sake of his own interest, Solness willingly lets Brovik die in sorrow by seeing to it that Brovik's competent son, Ragnar, must not be allowed to build. It is Solness's policy never to allow the younger generation to outshine him, especially when he feels that his success comes with a pervasive sense of guilt and ennui. He cannot forget the past - how the fire takes away his wife's happiness and the lives of his two boys. To bury his grief, Solness is ruthless in his pursuit of enjoyment and excellence-he uses Kaja Fosli to keep the best staff (Ragnar) for himself, and he is determined to build the tallest building in the neighborhood for his wife. The sudden arrival of Hilde Wangel upsets Solness's career and domestic projects: Hilde claims that ten years ago Solness promised to give her a kingdom and make her a "Princess," and she now expects him to build a "castle-in-the-air" for her. Solness soon takes the challenge as a libidinal and career breakthrough: he fulfils his promise to Hilde by building and sacrificing himself for his transgressive love and radical architecture.

The difference between the oedipal father and the post-oedipal father lies in their respective commitment to life or narcissism. In Dialectic of Enlightenment, Theodor Adorno and Max Horkheimer explain the rise of the oedipal father, highlighting the correlation between survival and rational repression. Adorno and Horkheimer cite the example that, by repressing himself and shutting out the Sirens' voices, Odysseus can control nature, but he survives at the cost that "selfpreservation destroys the very thing which is to be preserved" - that is, his innate desire. As humans cling to reason/repression in order to build laws and empires, ironically, excessive repression leads to the rise of "a new form of barbarism" and the destruction of enlightenment. ${ }^{4}$ Formal rationality pushes humans to become inhuman as the father becomes "Janus-faced." On the one hand, the father is ultralawful, for he welcomes instrumental reason so as to dominate others and himself. On the other hand, the father becomes ultra-lawless, for he needs "myths" to control reality and deflect the people's awareness of being dominated and exploited. Hence, he promotes activities to scapegoat others (e.g. Jews, misfits, weaklings), and allow for "orgies" of feeling. However, we are to note that if the father becomes perverse, and reverts to myths and barbarism, he is still consistent in his love of life and desire for collective/self-preservation: the emphasis is always on the destruction of others, never the self or the in-group.

Meanwhile, the post-oedipal father moves from the desire for life to the realm of the drive, favoring the pursuit of narcissistic jouissance. As noted by Joan Copjec, 
modern times are characterized by the fact that the old "order of desire ruled over by an oedipal father, has begun to be replaced by a new order of the drive." ${ }^{\prime \prime}$ In fact, the move is caused by the new father's first-hand knowledge that the order of life and civilization is a downhill journey. He sees that the oedipal father becomes feeble and is powerless to combat the negative changes. In addition, the old father is a perennial victim of repression and self-alienation. As a result, the new father is not into renunciation or sacrifice at all. In The Regime of the Brother, Juliet Flower MacCannell suggests that the new father simply wants to be a "father-child": he "retain[s]" the "name" of the father without feeling the slightest obligation to "exercise the paternal/parental function." Soon a new self_- "unconscious, superego, It - has begun its reign of pleasure and of terror." " Sidelining law and repression, the new father openly models himself after the primordial patriarch in the totemic paradigm.

The neo-totemic, post-oedipal realm thus begins where oedipal reason leaves off. The assimilation of reason/myth, culture/barbarism, and superego/id at the final stage of oedipal enlightenment paves the way for the new father to mythologize himself rationally. Uniting the powers of a libidinal child and a professional, the new father enters the Imaginary domain, liaises with the mythic totem, and makes a powerful alliance with mysterious forces. He chooses to see himself through myths (sometimes in the form of skin-painting, tattooing, and body-piercing), replacing the paternal superego with a paternal id, thereby, in the words of Mellard, favoring the "shift from the sexual family unit to the asexual model of the artificial collective mind." ${ }^{8}$ Wielding in him natural, animistic, and rational powers, the new father gains a totemic identity and loses no time in undoing norms, redefining family laws, toppling grand narratives, and relating ethics to no one but himself. In The Master Builder, Solness willingly "imaginarizes" himself, invokes the totemic troll and the servers to be his guardian spirit and helper. This act greatly transforms his life, for the new father can bypass all constraints and follow the sole commandment to enjoy himself.

The post-oedipal father is structured by the Symbolic discourse of reason, but he uses "reason" only to dominate others and direct all things to himself. If the traditional father is interested in self-preservation and scapegoating outsiders, the new father does not mind devouring the well being of his own children in order to benefit himself. Having freed himself from repression, the new father either bends the law or removes much needed laws or taboos so as to convenience himself. He soon invents a tyrannical master-discourse so that only he can hoard forbidden money and sexual adventures. Eventually, the new father does not mind being "the mother's lover," "his brother's lover," "his sister's boss," or in The Master Builder, a child molester. He works hard, but he is also happy with unjust monopoly, ruining people's futures, or bankrupting well-established companies overnight. Perhaps that is why Slavoj Žižek calls this new figure an "anal father," "Father-Enjoyment."10 
On the surface a competent leader, he is essentially an aggressive, irresponsible, ruthless tyrant. Even though the new father comes after the oedipal father, Žižek notes that he is a primordial despot instead of a progressive liberator: "from the French to the Russian, the overthrow of the impotent old regime of the symbolic Master (French King, Tsar) ended in the rule of a far more 'repressive' figure of the 'anal' father-Leader (Napoleon, Stalin)." As Halvard Solness declares "I am what I am," he justifies his narcissistic ethics as a civic duty. ${ }^{12}$ Soon rational calculation and irrational enjoyment join hands so that the father can deny all threats of castration, disavow people's wants, and allow no children to challenge his place. As he destabilizes people's understanding of laws, he makes sure that the world is unable to judge him, for no one (least of all the new father himself) can tell people what to think or do.

Having hoarded and consumed to his satisfaction, the new father seeks the highest jouissance in life - the Real symptom of (self-)love that is closely linked to death-desire (e.g. the ambitious pursuit of the impossible dream, radical sports, reckless romance). This symptomatic will-to-jouissance is fundamentally different from the Nietszchean will-to-power, a concept related to reform and life desire rather than narcissistic jouissance and the death drive. On the social level, this jouissance can bring only disaster. As the new father owns everything and has deformed the base structure and superstructure, MacCannell sees that he has set "the death drive in motion for others as well as himself." As he refuses to make changes, when the economy or the social body caves in, the new father has no way to undo the harm except to "enjoy" his downfall. On the personal level, death appeals to the new father for it can offer the greatest satisfaction in life: he can re-create himself and author his death, which brings "peace, repose, the cessation of tension and conflict." ${ }^{13}$ Without a high regard for preservation, the new father welcomes his end. Death is but the final act of "liberation."

\section{Oedipal Fathers: Old and New}

In The Master Builder, Ibsen gives a vivid contrast between the oedipal father and the post-oedipal father. The debate over the Lövstrand villa contract foregrounds different paternal discourses: the old father has faith in building up humans and building for humans, whereas the post-oedipal father's sole concern is about building up himself. Knut Brovik is a traditional father, or what Žižek calls a "father of law who does not enjoy" and often "ignores the dimension of enjoyment." "Although Knut Brovik famously proclaims, "I cannot bear it anymore," the old architect still endorses repression. First, Brovik has a lot of "covert hatred" toward his usurper, but he honors the pecking order and calls Solness "the chief." Second, Brovik suppresses his feelings just to be a good guardian: Brovik's strong pack consciousness is shown in his interest in tightening the communal bond, for his potential clients - the young couple — are friends of the family. Additionally, the 
old father is eager to build up his pack and witness the rise of a talented son worthy of his trust. For the sake of his son, Brovik confronts Solness when the play opens. However, he is shown to be an enfeebled character: with his lowly position, Brovik has little enunciative authority. His begging tone and failing health make him only a weakling. The strategic appeal to Solness's conscience gains him little ground, and Brovik's anger further reduces him to an even more pathetic state. He "reels" and has to ask his enemy for a glass of water and thank him. The conversation ends on a note of weak indictment: he tells Solness to "sleep well...if [he] can."15

Solness is schooled by the discourse of repression, for he "came as a boy from a pious home," and he had an "honest and warm and heartfelt devotion" to God. In short, Solness used to be a good Christian, a good father, and a good husband. His goal was to defend the tradition of religious, sublime architecture; thus he thought building Gothic churches was the "noblest task [to which he] could set [himself]." Likewise, he had the noble desire of putting his family before his self-interest. He built nurseries for his children, and he found it "snug and comfortable" to live in the old house of Aline's mother, even though the building looked like "a great, dark, ugly wooden box." 16

The failure of tradition under modern conditions perhaps makes the situation urgent and prompts Solness to make his move. Just as Doctor Stockmann is fed up with the way things are in The Enemy of the People, it is not surprising that Solness wanted to bring pre-modern architecture to an end, for the old house is a "grim old robber's castle" in the eyes of Dr. Herdal, and a "ramshackle old place" to Hilde. ${ }^{17}$ What seems unusual is Solness's method. If Ibsen loudly defends the enlightenment spirit in The Enemy of the People (the doctor's loud plea for critical reason and reform), in The Master Builder Ibsen anticipates Adorno and Horkheimer's view that myth is always a part of the enlightenment. Twelve or thirteen years ago, Solness staged his oedipal revolt by turning to the imaginary "helpers and servers." He invoked these mythic powers in the hope of becoming a totemic "anal figure that is real-alive, the "Master of Enjoyment." ${ }^{18}$ As a result, Solness gained an imaginary identity and thought he was a "chosen" professional with psychic powers: he had been "endowed with the power and faculty of desiring a thing, craving for a thing... [until] at last it has to happen." ${ }^{19}$

It is interesting to ponder the role of the Imaginary in self-formation and further compare the magic wishes of the primitive people and Solness's worldview to the mind of Rat Man. To the primitive mind, spells can influence the weather. Thus Sigmund Freud suggested in Totem and Taboo that primitive people often overvaluate imaginary ideas and wishes, for primitive men's "process of thinking is...to a great extent sexualized" and infantile. If primitive men believed that the Imaginary could magically govern real things, this form of belief survives in modern adulthood in the form of infantile megalomania. Freud says Rat Man is a case in point: Rat Man coined the phrase "omnipotence of thought" as "an explanation of 
all the strange and uncanny events by which he, like others afflicted with the same illness, seemed to be pursued."

If [Rat Man] thought of someone, he would be sure to meet that very person immediately afterwards, as though by magic....If, without any really serious intention, he swore at some stranger, he might be sure that the man would die soon afterwards, so that he would feel responsible for his death. ${ }^{20}$

Like Solness, Rat Man confuses coincidence with causation, leading to the rise of erroneous conscience and misplaced guilt. However, the point is that the Imaginary allows the subject to experience mystical self-empowerment, to liaise with unnameable forces, attribute mysterious powers to the self, bypass all laws, narcissistically wish for unlawful/tabooed things, or actualize what Solness calls "the impossible." His imaginary self is not unlike that of Rat Man, for he thinks he has become a troll-man and is responsible for the outbreak of the fire and the death of his sons. ${ }^{21}$ The new father can see everything through the omnipotent mirror of his bad logic. Armed with magic thinking, technical knowledge, the servers' help, and the drive to seek what he thought was his "due," Solness quickly toppled the fatherly kingdom of Brovik. He became a totemic leader by taking "the wind out of [his and many other people's] sails."

And the old house must go. The fire marks the new father's disavowal of particular ties, for it destroys Solness's family and leads to the death of his children. At first, Solness argues that the destruction of the oedipal household could be good. The fire is a golden opportunity that makes him "an accomplished master in [his] own sphere - so that [he] might build all the more glorious churches for [God]. ${ }^{22}$ When he was "building the church-tower up at Lysanger," he argued he had merely used evil means to advance the "greater good," as his goal was to be God's first-class servant. However, his self-love prompts him to retract quickly from this position.

As the totemic father is a self-serving character and never a servant, Solness quickly renounces all universal ties; he realizes he "had no heart for building churches." ${ }^{23}$ He blames it on the death of the boys, but another probable reason is that the new father cannot withstand any constraining forces. In the words of MacCannell, the post-oedipal father makes sure that he is "to install the rule of the contemporary, the same generation, over the rule by the dead, the elders." ${ }^{24}$ Solness's interest is quickly redirected to the pursuit of the egotistical sublime. Aided by the servers and helpers (for he is afraid of heights and "never sing[s] a note in [his] life"), Solness literally "force[es] his way upwards," and climbs up "a great, free height" so as to make an irreligious speech that is later misinterpreted by Hilde Wangel to be a song. His climb not only makes him a towering figure, but also allows him to transgress social limits. The phallic posture demonstrates his (sexual) assertiveness, 
and Solness further proclaims to the world his sovereignty, for he sees himself as a rising master who "will be a free builder . . . in [his] sphere-just as [God] in [His]." ${ }^{25}$ It is no wonder that after his descent he immediately interests himself in a little girl. Meanwhile, Solness also wants to mark the land with his creations. His narcissistic ambition is disguised in the form of an altruistic project: for ten years, Solness devotes himself to the development of a "utilitarian" architecture. The pre-modern Gothic towers are gone, and his vernacular architecture becomes a commodity under a new motto-_house for the people."

Like the primordial despot, Solness's neo-totemic status is shown by the fact that he is the head of his clan (profession), and the troll becomes a part of him, and is more than him. An animal cult has always been important in the totemic paradigm. For example, in The Origins of Religion, Freud writes, "What is a totem? It is as a rule an animal (whether edible and harmless or dangerous and feared), which stands in a peculiar relation to the whole clan." In this play, we are reminded that the Viking ancestors and Solness are both linked to the image of the troll. If Freud suggests that the old totem is "the common ancestor of the clan," "their guardian spirit and helper who sends them oracles and, if dangerous to others, recognizes and spares its own children," the neo-totem displays no such protective function. ${ }^{26}$ For the new father in The Master Builder, the troll is related to life as well as death: the troll gives Solness a new life by giving him a new career; however, Solness's career comes with the death of his sons. The troll gives Solness a new love-life, but this love directly leads to his death. It is interesting to see that the troll makes Solness a master, but Solness is also its slave. As a result, Solness notes his doomed situation: "For it's the troll in one, you see-it is that that calls to the powers outside us. And then you must give in-whether you will or no." ${ }^{27}$

Guided by the troll imperative, Solness is anything but a protector. He is capable of doing "ugly," "hard and bad and cruel" things. The "troll within [him . . . has] drawn all the life-blood out of Aline" and "trodden [Ragnar] under foot."28 Meanwhile, the troll also made the new father seduce a young girl ten years ago. It is a classic scenario in the Freudian theory of seduction: after coming down from the scaffolding at Lysanger, he had a great dinner, went to Dr. Wangel's house, and saw Hilde in her lovely white dress. The perverse father kissed the sexually unprepared Hilde, a twelve- or thirteen-year old girl, when they were alone. In Freudian terms, this is a "primal situation": the perverse adult indulges in infantile seduction and enjoys the passivity of the child. Jean Laplanche notes that "here we have the seducer and seduced, perverter and perverted," for the "father-child" will not let go of the child before him.

Given that the child lives on in the adult, an adult faced with a child is particularly likely to be deviant and inclined to perform bungled or even symbolic actions because he is involved with 
his other self, with the other he once was. The child in front of him brings out the child within him. ${ }^{29}$

It is in this context that Solness reverts to the use of infantile language. He promises her that, "like a troll," he will come and carry her off ten years later, giving her the "Kingdom of Orangia" and naming her "Princess Hilde." ${ }^{30}$ After his return to the oedipal household, Solness quickly puts behind him any memory of his perverse sexuality. ${ }^{31}$ When Hilde confronts Solness in Act 1, he cannot accept the fact that he had touched her; instead he says, "I must have wished it—have willed it—have longed to do it." Finally, he suggests that the event may have happened, and it is always "the troll within" that accounts for a person's behavior and choice of love. ${ }^{32}$

Now it is clear why, all of a sudden, Solness starts talking about the ancestral Vikings, for they tie in with his totemic desire to possess more women and properties. There is a strong affinity between Solness the troll-man and the Viking fathers - for both love to hoard wealth, women, and subsequently proclaim "legitimate" ownership of other's belongings. The imaginary troll unites them as a clan, and these clan-chiefs cling to the ideological awareness that aggression or exploitation is an empire-building process regarded as acceptable. Solness notes how the Viking fathers are legitimate plunderers: "like the worst of trolls," they knew how to make room for themselves by sailing "to foreign lands," and they "plundered and burned and killed" to their satisfaction. More importantly, he also sees something romantic in the barbaric destruction of the oedipal household: the Viking fathers "carried off women" and "kept them in captivity." Solness then gingerly puts forward the idea that perhaps some captives — out of "free will" - may come to love ruffian-captors, to which Hilde answers in the affirmative. As Hilde openly acknowledges that she also has a troll inside her, and the devil has chosen for her love "already — once and for all," it is just a matter of time for the troll-in-Solness to respond to the troll-in-Hilde. Soon Solness will come to love Hilde, and they will join forces to violate social taboos. They are going "to build the very loveliest ... thing in all the world" together. ${ }^{33}$ Solness's worldview somehow agrees with Heinz Politzer's observation that three ideas- "Love without reserve! Enjoy without restraint! Live without dead time!" - characterize the essence of post-oedipality. ${ }^{34}$ Perhaps that is why MacCannell notes that the new father may seem "freer," but he actually "licenses many abuses, especially sins against 'natural' groups (families) and communal forms (tribe, clan, ethnicity) that [he] was supposed to symbolize, enable and endorse. ${ }^{{ }^{35}}$ I can only imagine that Ragnar cannot agree more.

In The Master Builder, Ibsen foregrounds the birth of a ruthless petit bourgeois. Solness becomes a Subject because he masters the Symbolic discourse of capitalism, of which he constructs his own cannibalistic brand. To gain his land-capital, Solness sees that "the lives of the two little boys had to be sacrificed." 36 To keep money and human capital for himself, he exploits his staff and symbolically devours the 
fruits of their labor, thereby cancelling the classical ethics of justice. ${ }^{37}$ In place of imaginary enchantment, the new father-entrepreneur has no scruples in endorsing instrumental reason at this stage. Solness is the bona-fide economic man, as every action is about prosaic calculation and the routine administration of a world dominated by him. Eventually, the office's division of labor is rationalized in terms of "efficiency" or "cost-benefit analysis" - only to make sure that Solness is the sole master who can enjoy all the surplus profit and surplus jouissance. Hence, Ragnar says that "[Solness] is not afraid of robbing others of their life's happiness." ${ }^{38}$ It is also helpful to note Žižek's differentiation between management that aims at preservation and "excessive" management. Solness's management style goes beyond the pale, for he does "things which went beyond his own modest survival, and brought him excessive material and professional gains or power." ${ }^{39}$ As shown below, Solness uses devious means to run his company and consolidate his position by heightening the constraints of all.

Solness's management policy is simple: he is determined to symbolically cut anyone's throat to avoid cutthroat competition. Even though Solness may feel very tired, he tells Brovik that he will not make room for the young: "[he] will never retire!" He feels he has labored for "nothing," but Solness the entrepreneur still defends the idea of monopoly:[ Only] I ought to be allowed to build." ${ }^{\prime 4}$ Having made his mark in the field, Solness represents how the new father can no longer respect the (old) economic discourse that allows open competition, although such is the condition for his rise (given his lack of proper credentials). The new father "cruelly rejects all forms of social solidarity as counterproductive sentimentalism." ${ }^{\prime 41}$ He may seem eager to build cozy houses for the next generation, but he is equally eager to suppress young talents and kill class mobility. In Act 1, Solness wants to build the villa once he knows Ragnar is interested in this project. A self-taught master, Solness is good at handling knowledge transfer; however, his hidden agenda is to make sure that Ragnar "has learnt nothing" in his office. The new father invents a new master discourse, i.e., the introduction of capitalistic serfdom. Solness openly tells Brovik, "your son will stay with me as long as ever he likes." ${ }^{\text {" To }}$ To the narcissistic father, humans are reductively viewed as either tools or threats, never assets.

Meanwhile, Ibsen also presents to us the new father's view on human resources management - in the form of "instrumental romance." As an anal-character, Solness loves to hoard affection - even though it may bring only inconvenience to him. Dr. Herdal knows that Solness has "known a good many women in [his] time" and has "been a good deal taken with some of them, too." Solness never denies this truth, for his philosophy is that he "cannot live without joy in life!" When the play opens, Ibsen presents a (false) love triangle. From the conversation that follows, we are to know that Solness merely uses the lover's discourse to manipulate Kaja and keep Ragnar working for him. This triangle shows that the father has a unique view of control: instead of rewarding his staff with money or prospects, Solness 
resorts to devious means to retain them. Solness makes Kaja become very "nice and willing to do whatever [he] asks of her." In other words, Solness is a symbolic lover hoping to make Kaja a genuine lover, while he pretends to be an infidel to make Kaja a true infidel. It is easy to see that Solness does not mind violating relationship taboos. His behavior is unethical in several senses: he upsets Aline, drags Ragnar's love life into office politics, and expects Kaja to go beyond the parameters of work, to "work" for him. He mixes formal economy (the impersonal wage labor) with informal economy (the labor of love). Ironically, the new father does not find his success enjoyable, for he concludes that the business of Kaja is "a cursed nuisance." ${ }^{43}$ However, he thinks he must go on because, in his eyes, this corrupt game is "business."

It takes Solness ten years to realize that his modern architectural vision has succeeded and yet failed, for he ends up building many iron cages. Solness builds extensively, going after the "mathematical sublime" to mark the land with his creations. He has built many "cosy, comfortable, bright" houses; he wants his houses to allow "father and mother and the whole troop of children" to live "in safety and gladness, feeling what a happy thing it is to be alive in the world." However, as Solness is a destroyer of particular and universal ties, his office is an iron cage, his houses cannot be homes, and his new home cannot reinstall the bourgeois family system. Unlike the Hegelian master, Solness the master labors too much, only to know that a high price has to be paid "every single day" because he has to "keep on flaying pieces of skin off other people in order to close [his] sore!-But still the sore is not healed - never." And he finally realizes that the product of instrumental reason can only be iron cages that destroy not only "[his] own happiness," but "other people's, too." 44

This play allows the reader to see that the new father is a pain-filled master as well as a fearful slave. Solness becomes a legendary modern builder, but he feels the full force of oedipal guilt for he has symbolically "killed" his former employer, his faith, and his family. Meanwhile, he is also a (primitive) man of fear: he is naturally afraid of heights, he fears that God may punish him, and he is worried that the helpers may stop helping him, the young generation may finish him, and Ragnar might "come to the front." 45 In the words of Theipharis Constantine Theoharis, "Solness has divided against himself": "Criminal and judge in one, Solness uses guilt to stay alive. He has split himself into acceptable and unacceptable parts whose tense relation makes his life a disease." 46 The master's ennui and the slave's fear make Solness a bitter character: he realizes that, while he has "staked his whole life" on building houses, he feels that "building homes for humans beings . . . is not worth a rap." He is so tired that he thinks he shall not "build much more." 47 Thus George Bernard Shaw comments that "The Master Builder is a dead man before the curtain rises. ${ }^{" 48}$ Interestingly, if Solness is spiritually dead, he uses conflicts to defend his diseased hegemony. Solness uses his "salutary self-torture," "sickly conscience," 
and fearful insecurity to cling all the more to his empire. As a result, he refuses to help Ragnar, and simply tells Brovik to resign to fate: "You must pass out of life as best you can." He lets Knut Brovik die "in utter poverty."

\begin{tabular}{|l|l|l|l|}
\hline & Identification & Women & Architecture \\
\hline The Oedipel Phase & Family and religion & $\begin{array}{l}\text { Aline } \\
\text { (a living-dead wife) }\end{array}$ & $\begin{array}{l}\text { Pre-modern architecture } \\
\text { Gothic churches } \\
\text { (religious sublime) }\end{array}$ \\
\hline $\begin{array}{l}\text { The Post-Oedipal } \\
\text { Phase: } \\
\text { Totemic Imaginery }\end{array}$ & $\begin{array}{l}\text {-The Imaginary helpers, } \\
\text { servers } \\
\text {-Solness becomes a } \\
\text { troll-man, a slave }\end{array}$ & $\begin{array}{l}\text { Hilde Wangel } \\
\text { (a young, innocent child) }\end{array}$ & $\begin{array}{l}\text { Modern architecture } \\
\text { "Happy homes" } \\
\text { (egotistical sublime) }\end{array}$ \\
\hline Instrumental Symbolic & $\begin{array}{l}\text {-the Symbolic discourse } \\
\text { of capitalism } \\
\text {-Solness becomes an } \\
\text { inhuman master }\end{array}$ & $\begin{array}{l}\text { Kaja Fosli } \\
\text { (a performance fiancée) }\end{array}$ & $\begin{array}{l}\text { Iron cages } \\
\text { (mathematical sublime) }\end{array}$ \\
\hline Real Symptom & $\begin{array}{l}\text {-the Real love drive } \\
\text {-Solness becomes a } \\
\text { lover }\end{array}$ & $\begin{array}{l}\text { Hilde Wangel } \\
\text { (a femme fatale) }\end{array}$ & $\begin{array}{l}\text { Anti-modern architecture } \\
\text { The castle-in-the-air } \\
\text { (a sublime place-world) }\end{array}$ \\
\hline
\end{tabular}

Different phases of Halvard Solness, his women, and his architectural visions.

\section{The Three Graces: Tomblike Wife, Performative Fiancée, Bird Woman}

Of course, Solness is surrounded by three women. His narcissistic jouissance has introduced great changes to all of them, for Aline, Kaja, and Hilde are not traditional characters. According to the psychoanalytic tradition, the oedipal mother clings to male discourse and sees her children as her imaginary phallus. On the surface, Aline is a textbook example of oedipal motherhood, for she talks about her lost children and is obsessed with male discourse, especially the Kantian imperative to do her "Duty—duty—duty." Unlike Hilde, who sees duty as a castrating, "horrid word," so "cold and sharp and stinging," Aline practices repression to be a docile wife, although she admits that it is not easy: "It is only my duty to submit myself to [Solness]. But very often it is dreadfully difficult to force one's mind to obedience." ${ }^{, 50}$ Ironically, Ibsen presents Aline as if she were the model oedipal mother, while in fact she is not.

The truth is that Aline is a preoedipal woman, for she does not need anybody or the phallus at all. Not suffering from penis envy, or devoted to duty or childcare, Aline's subjectivity manifests a blatant disavowal of motherhood. Aline is not, as James Calderwood says, a character who embraces "selfless Christianity," for she has long been indifferent to the feminine ethics of care. She cold-heartedly says the loss of her twin boys "was a dispensation of Providence; and in such things one can bow in submission . . . and be thankful." "51 The truth is that Aline deeply treasures her narcissistic, preoedipal self, which prefers objects to humans. Hence she bonds with toys (or what Donald W. Winnicott calls transitional objects) rather 
than symbolic laws, for these objects accompany a child and allow her to gain a pre-established harmony. She can function because of this imaginary (half maternal, half companionate) world order. ${ }^{52}$ Under such circumstances, it is no wonder that Aline puts her dolls first. She has no milk for her children, but she has tears for her lost dolls.

Aline's dolls carry different functions from the dolls in A Doll's House, for Nora's are the symbolic dolls of the Other and can subsequently lead her to the paternal world (i.e., men posit women as dolls, so Nora follows the male dolldiscourse to otherize herself and get what she wants). However, Aline's dolls represent her preoedipal alter-ego, transitional objects that sustain her narcissistic domain. Thus she says, "there was life in [the dolls] too. I carried them under my heart—like little unborn children." In other words, her dolls are her agalma, the precious objects that disavow the introduction of lack in the paternal symbolic, although these dolls have fast become her "obscene enjoyment" for she should have long outgrown this phase. Aline understands the duplicity of her state of being and actively hides her disavowal of oedipal womanhood. She makes sure that "[Solness] did not see it."

Aline is reduced to an abject, tomblike condition, for the fire robs her of her dolls, and her lack of the dolls results in the drying up of the milk, which subsequently leads to the loss of the boys (the phallus) - an event Solness keeps talking about (the procreative "lack" in the paternal discourse). Her double lack makes her suffer greatly. In the play, Aline's role alternates between her status as a homeless alien (due to her lack of preoedipal fullness) and a homely hostess (due to her forced acceptance of her lack of phallus in the oedipal symbolic). She finally tells Solness that she knows she has a big house but no home: "You may build as much as ever you like, Halvard — you can never build up again a real home for me." No matter how big her garden is, Aline has no interest in it: "Everything that was mine was burnt." Though she follows her duty to welcome the Other, she actually hates the Other, for she sees the Other as the cause of her "loss": "They have taken away so much - so much of the garden, Miss Wangel. Fancy-they have parcelled it out - and built houses for strangers - people that I don't know." Hilde intuitively senses the painful existence of Aline, whom she compares to a "tomb." And after talking to Aline, Hilde feels as if she had "just come up out of a tomb [where she] got chilled through and through." ${ }^{\prime 54}$

"Duty" has developed different meanings for Aline. She embraces her duty in order to disguise and hide her self and her disengagement with oedipal motherhood. Her effort is characterized by her becoming "more Other than Other" so that she can avoid being accused of her preoedipal femininity. The cost is great: speaking the language of the Other, she secretly rebels against the demand of the Other. One example is that, although she seems to care about Solness, Aline actually avoids her husband as much as possible. Thus Solness says, "Have you noticed ... that as 
soon as I come, she goes?" In the final analysis, Aline prefers to heed trivial calls to paying attention to Solness: "God knows that it is my duty [to talk to people]. But when one has duties in so many directions_- " 55 An important consequence is that Aline quickly leaves the job of dissuading Solness from climbing the churchtower to Hilde, not knowing that Hilde is the architect of the project.

In contrast to Aline's victim mentality, Kaja is a resourceful performer. She is engaged to Ragnar, but the moment she sees Solness, she reckons that he must be in need of her. In fact, the whole business surprises Solness, for Kaja Fosli came to his office alone the very next day after she first met him and "behaved as if [he] had made an arrangement with her." "Miss Fosli" is regarded by Hilde as a "cold" symbol, but Kaja surely knows how to play any game into her hands. She acts submissively before Aline and passionately before Solness. She lies to Aline about the nonexistent letter and bends her head before Solness and lets him stroke her hair. In short, she is a great performer who can mask her status or triangulate her love life. Although she talks romantically and tells Solness, "there is only one person I care for now! One, and one only, in all the world! I shall never care for any one else," her notion of "true love" is that - when Solness says she can marry Ragnar so that he can keep seeing them both-Kaja will say "how lovely that would be, if it could only be managed!" This cold subject carries a distinctively modern outlook, for her performances are linked to role calculation and profits. She says she loves Solness, but she is equally happy to advance the interests of Ragnar by presenting his drawings to Solness, while telling Solness to "think kindly of [her]. ${ }^{" 56}$ Her flawless/lawless linguistic performance makes her a winner in the play: without Solness, she still has Ragnar.

Meanwhile, Hilde is a post-symbolic child-woman. Hilde's desire is first constructed by the discourse of the Other (Solness), but she soon turns it around to negate him, thereby disavowing her lack and castrated status. For example, Hilde's symbolic universe was nicely set up by Solness when he tells her to be his "Princess" someday. However, the inversion of the master-disciple relationship soon takes place: Hilde goes beyond the signifiers of the father and creates a law for herself. Her new law is that she uses Solness's language to tax him: she puts her "master" on a pedestal and forces him to live up to her demand and confront the deathliness of the paternal symbolic, the "Hero" discourse. Right from the beginning, Hilde's mystical enjoyment is linked to a paradoxical desire, to see the rise and fall of Solness. On the one hand, Hilde loves the master builder and wants his career to reach new heights; on the other hand, she repeats the master's motto that happiness comes only at a high price: someone has to suffer and die. In fact, Hilde likes to see Solness up a tower because she finds it "tremendously thrilling" if he may fall. And when she yells, "Hurrah for Master Builder Solness," her intention is not just to celebrate his career achievement; she is actually turned on by the "fancy" that "he should fall.", 
Under such circumstances, Hilde is anything but the oedipal girl in Freud's seduction theory. ${ }^{58}$ Instead of resorting to repression or hysteria, Hilde cherishes the fantasy and simply sees Solness's seduction act as "the real thing." She vividly recalls all the details and has great pleasure in reconstructing the primal scenes. Like a textbook case of Stockholm syndrome, the seduced enjoys being seduced and eventually becomes the seducer; thus Hilde feels no trauma and says she "can understand exceedingly well" that some women may want to live - out "of [their] own free will" - with the Vikings or ruffians who carry them off. In short, infantile passivity matures to become infantile aggression, and the sexually abused finds great delight in perversely abusing the abuser. In this context Hilde builds her non-oedipal outlook of life, which is admired by Solness in terms of "robust conscience." In the play, Hilde's excitement is constantly linked to hunting and death. She says she is happy to be the "wild bird of the woods" who preys on men. She tells Solness to his face, "Why should I not go a-hunting — I, as well as the rest. Carry off the prey I want - if only I can get my claws into it and do with it as I will." In fact, she has a strong desire to topple iron cage modernity, and follow the "Viking-spirit"-for "the wild bird never wants to go into the cage."

This is why, in spite of her girlish appearance and "tourist costume," Hilde is not, as William Archer says, a character who represents "ardent transcendentalism," nor is she as James McFarlane claims, "the embodiment of the confident Nietzschean amorality of the wild animal, 'thrilled' by life's encounters. ${ }^{960}$ Ibsen makes Hedda Gabler a ruthless woman who destroys others out of "necessity"; however, Hilde is a bona-fide perverse femme fatale who enjoys hunting and ruining men. Hilde is a carefree woman, but she is far more dangerous for she uses the male Symbolic to ensnare men, and she enjoys destruction for destruction's sake. Hilde knocks on Solness's door the moment he is thinking that the young generation might finish him. This is her job, but Solness's fear is still misplaced: instead of being killed by the young people's oedipal complex (the oedipal, lawful generation of retribution), Solness is killed by the post-oedipal child-woman's perverse play/prey drive.

The new father is responsible for producing a femme fatale who dooms him. His greed for love and his language all help ground Hilde's future subjectivity. First, Hilde models after the new father's tendency to abandon the old father. Thus she leaves Dr. Wangel's house, gives up reading books ("all seems so irrelevant"), has no luggage, and does not care how others see her. Second, she imitates Solness's exploitative tendency, and loves to "[c]arry off [her] prey." Solness immediately sees that he and Hilde are like-minded: both have trolls inside them, and both are self-liberating creatures who abandon laws and repression. If Solness feels that the troll in him desires the burning of the old house so that he can get his elbow room, the troll in Hilde makes her feel an "impulse" has "urged and goaded [her] to come - and lured and drew [her] on" to get her "kingdom." Thus, instead of feeling afraid, Solness welcomes Hilde and says she helps counter the young generation. 
The situation will be like "Youth marshalled against youth!" When Solness asks, "How have you become what you are, Hilde?" she immediately replies, "How have you made me what I am?" The saving grace for Hilde is that she cannot harm Aline the mother. As a result, she suddenly says she wants to leave Solness because "I cannot do any harm to one whom I know! I can't take away anything that belongs to [Aline]. ${ }^{\circ 1}$ Ironically, as Aline actively puts her husband's fate in the hands of Hilde, she quickly sends the father to his grave just to make him play the hero for her. ${ }^{62}$

\section{The Real Symptom: the Lover}

To Lacan, the "subversion of the subject," means that the Symbolic subject of thought is suddenly overthrown by the subject of symptom in the drive. Unlike Bernick in The Pillars of Society, who ultimately returns to the old master discourse to resurrect traditional ideals such as truth and freedom, Solness in The Master Builder is toppled by his urge to follow his symptom, and he stakes his life to follow it. Žižek rightly notes that a subject can place his symptom above all else:

Someone can be happily married, with a good job and many friends, fully satisfied with his life and yet absolutely hooked on some specific formation ("sinthom") of jouissance, ready to put everything at risk rather than renounce that (drugs, tobacco, drink, a particular sexual perversion ...). Although his symbolic universe may be nicely set up, this absolutely meaningless intrusion...upsets everything, and there is nothing to be done, since it is only in this "sinthom" that the subject encounters the density of being — when he is deprived of it, his universe is empty. ${ }^{63}$

In The Master Builder, the symptom turns out to be none other than Solness's (self-) love. In the past, he could love himself only qua his career and his master status, while now he can love a new Solness qua the words of Hilde. Having not seen Hilde for ten years, their "love" cannot be very substantial. However, the ethics of the narcissistic drive lies exactly in answering the interpellative voice of Hilde, for Solness can merge his self-love with the love of the other, his adulterous desire in the private sphere, with architectural achievements in the public domain. Through the lover's identity, he is no longer a master of other builders or a slave of the troll; instead, he can be Hilde's hero, an immoral rebel, and can reinvent himself. If he lives on, he can be reinvigorated and build the kind of pointed buildings that they both like. If he dies, he can break the postoedipal cycle of tiresome hegemonic hoarding, as well as the oedipal cycle of sickly conscience to regain his peace. In addition, through a self-administered death, Solness can be a legislator of his life. He can "throw off the one-God, the king, the father-to replace it with the 
grammatical and legal and emotionally empty fiction of an I who stands alone and on its own: 'his majesty the ego." "'64

Hilde is not the cause of Solness's fall, although her role is crucial for the postoedipal father can see in her the deadliness of his drive ${ }^{65}$ In other words, the hero cannot help loving a femme fatale precisely because he is a lover of himself, he wants to disavow castration, hence he must live up to his larger-than-life persona pointed out to him by her. In the play, Hilde is powerful because she externalizes Solness's counter-castrating longings: tall buildings are meant to defy the law of gravity, and when Hilde asks him to build "something that points - points up into the free air... at a dizzy height," Solness immediately agrees: "Strange that you should say that - for that is just what I am most anxious to do." Solness wants to surpass himself, and when Hilde asks him to climb the tower and "do the impossible again," he agrees and says he must make another speech, and then "[he] shall go down and throw [his] arms round [Hilde] and kiss her...many, many times." Although Solness knows Hilde is dangerous ("I believe there is scarcely a corner in me that is safe from you"), Solness must heed Hilde's demand. ${ }^{66}$ Unlike what Inga-Stina Ewbank says (Solness's "real 'debt' is the 'kingdom' promised at Lysanger and being cashed in as a 'castle in the air"'), ${ }^{67}$ Solness's real debt lies in his relation to his ego drive. His ego loves to know- "what am I in the Other's desire?" Unable to withstand Hilde's taunt ("my master builder dares not—cannot—climb as high as he builds?") ${ }^{68}$, Solness reiterates his determination to climb the tower and "sing" again.

In the play, the castle in the air is the femme fatale's perverse fantasy-an emergent discourse that defies the male discourse of lack, the law of gravity, and the reality principle. It also serves as a contrast to negate Solness's vernacular, utilitarian architecture (only "He"- the master builder — can mark the landscape, or build "happy homes for mother and father)." Hilde's perverse fantasy is attractive for Solness knows his social vision has failed. He says, "I don't believe I shall build anymore"; however, after talking to Hilde, Solness immediately says, "I am just going to begin!. . I believe there is only one possible dwelling-place for human happiness - and that is what I am going to build now." The master is convinced by Hilde's castle in the air because, instead of the oedipal, reproductive family unit, this castle offers something radically different. In the asocial aerial domain, he can bypass bourgeois morality, possess a different woman, and confront the power of heaven and hell. He can become a feudalistic lord to redistribute happiness and recreate reality. Thus he tells Hilde, "You must have the topmost room in the tower, Hilde - there you must live like a princess. ${ }^{"}{ }^{9}$

The aerial castle is "emancipatory," although we must note the different male and female reactions to this fantasmal discourse. Hilde finds the aerial castle a good thing for she can have her castle immediately. The castle can also give her a different perspective: she can look at how people are mundanely "building churches, and homes for mother and father and troop of children." It also offers a different 
set of ethics so that Solness can enjoy their sweet adulterous union with no qualms of conscience. However, Hilde is openly "scornful" of its artificiality. She says sarcastically, "Castles in the air - they are so easy to take refuge in. And so easy to build, too . . . especially for the builders who have a-a dizzy conscience." In the play, her attitude on the castle alters between "earnest and jest," demonstrating at times an "outburst of pleasure" or a "half-dubious smile," at others "vehemence" or "repulsion." While it is true that she loves to see Solness in his glory, her enjoyment of the castle lies in witnessing Solness's death, for the lethal jouissance of the femme fatale cannot be satisfied until she has the most precious thing out of him-i.e., the kernel of his being, his life. Hence, when everyone is shocked by Solness's downfall, she feels only an ecstatic joy - a "spell-bound triumph" at the master's genesis of a new self, his death. ${ }^{70}$

On the contrary, Solness considers building the castle an anti-modern move, a mark of his sublime symptom. However, as David B. Morris notes, it is a sublime "utterly without transcendence. It is a vertiginous and plunging - not a soaring - sublime." ${ }^{.71}$ The castle directly leads to his death, which can carry different interpretations. ${ }^{72}$ What is revolutionary about The Master Builder is not so much about having a feudalistic, adulterous castle in the capitalistic, middle-class home setting, but Solness's rewriting of architectural imagination. Edward Casey has differentiated two types of architecture: space architecture refers to the pre-modern, phallic, hierarchical buildings and the modern space which is abstract and universal, with an endless totality (e.g. the traditional castles and the happy homes). On the contrary, (the Bachelardian) place architecture links the psyche and the body to space. Such place offers a distinctive jouissance that unites "being and non-being, having and lacking, there and not-there: the form of the universal and ideal human (vertical, virile, phallus- and logos-possessing, erect, self-created, masculine/male) and the form of the particular, wounded or de-formed human (those who lack logos, the phallus, and verticality)." ${ }^{73}$ In the final phase of Solness's career, he sees that there is only "one possible dwelling place" for him. ${ }^{74}$ The aerial castle becomes a privileged topos because, instead of creating more rational space, or alienation between dreams and reality, the self and the other, buildings and cosmos, the new castle links dwelling to in-dwelling. In the past, Solness was a builder who remained separated from his buildings; however, the castle in the air features the process of "implacement." 75 Hilda and Solness poeticize their thinking, and they discover in the imagined place a new intimate in-dwelling, a felicitous space. The castle is the "loveliest thing" that dramatizes the convergence of material imagination and inhabitational centeredness. Inhabitation no longer refers to a solid house but the creative "infusion" of minds. Solness is in the center of the castle for Hilda, but through the castle, his psyche is also drastically changed. Solness's new architecture overcomes what Derek Gregory calls the "cartographic anxiety," the fear about the lack of firm foundation, the lack of ground. Solness forfeits his previous space- 
obsession, his "ontomania" - the need to hold on to masculine, positional, social, affective, geographical space. ${ }^{76}$ Instead, the aerial castle welcomes psychical immanence and brings together a new form of being, building, and in-dwelling. Solness's aerial castle defends psychological togetherness, sensuality, id; it forms a resistant realm to fight against the abstract, mathematical dimension of modern architecture.

In the play, the castle in the air is built using Solness's body or is actually his body; thus the building embodies his phallic presence and his wound, his being and non-being in the world. Solness's body transforms the conventional notion of architecture. This place-architecture is "lived," "kinesthetic." It is also a nonthing, an imaginary construct that is "ephemeral and event-like." This imaginal building anticipates the view that "place is the event of 'taking place,' an event that happens in ever-different ways and leaves behind itself the residue of unique places." ${ }^{\text {78 }}$ Meanwhile, the aerial castle also changes the body of Solness. The lived body of Solness becomes a place - an arena of action that is affective, physical, and creational. It foregrounds two important happenings pointed out by Casey, i.e., "outgoing" and "incoming." The builder's "lived body encounters the place-world by going out to meet it," resulting in the "up/down, front/back" movement of the body, hinting at the "verticality, frontality, horizontality" of the place. In turn, the castle interacts with the builder. The place is energized and transformed by the builder's body, and the builder's "incoming" refers to the fact that the body is "shaped by" and "bears the traces of the places it has known." Solness constructs the castle, and his physical being is altered by the castle: "In contrast with Kant's view that we construct space by a formal transcendental activity," Casey sees that the new builder is not just a master "of place but also prey to it." He can end up carrying "the peculiarities of place in his very flesh." story, Solness is not only in the castle, he is the castle; he creates and is subject to the influence of the castle. The towering castle is open for all to see, and yet it is empty and private. Solness's destroyed body can symbolize a null-point, but the imaginal field enjoys a powerful afterlife. As noted by Casey, the "sense of place that counts" is "not that of place as it contains and perdures but as it lights up with the sudden spark of a single striking image, like a shooting star in the dark abysm of night. ${ }^{.80}$ The castle is an ephemeral event, but it also offers to Hilda an eternal memory of thanatic eros.

The Master Builder gives us a disturbing message: the oedipal paradigm is in a declining state, but the post-oedipal paradigm can only generate more problems. Aline has a self-entombing mind; Kaja is a cold performer. Solness is a troll-man who has successfully reinvented himself and architecture, but his crushed head also implies desublimation, a return to vulgar reality. Meanwhile, Hilde is a femme 


\section{fatale who preys on men, but her trophy is a shattered corpse. These subjects cling to their idiosyncratic cravings, but the embrace of their symptomatic jouissance can only mean disaster, as they value transgression above law.}

\section{Notes}

1. For example, Moritz Prozor reads the play symbolically: "Solness is Ibsen himself; Hilde stands for youth and imagination; Mrs. Solness signifies the Past; Old Brovik is routine; Young Brovik is modern utilitarianism" (Qtd in Kirsten Shepherd-Barr, Ibsen and the Early Modernist Theatre [Westport: Greenwood P, 1997], 121). Peter Whitebrook posits the play in the Norwegian tradition: "Solness sees within himself the spirit of the troll, thought to be a race of curious dwarves living in mountain caves and representing the fantastic and evil forces in mankind." See Peter Whitebrook, William Archer (London: Methuen, 1993) 149.

2. Quoted in Michael Meyer, Henrik Ibsen: A Biography (New York: Doubleday, 1971) 696.

3. Edward Casey, The Fate of Place (Berkeley: U of California P, 1997) 289, 291, 292. In Chapter Twelve, "Giving a Face to Place in the Present: Bachelard, Foucault, Deleuze and Guattari, Derrida, Irigaray," Casey introduces different types of places and place-architecture, ranging from the Bachelardian imaginary topography, the Foucauldian heterotopic sites, the Deleuzian nomad space, the Derridean anti-sites, and the Irigarayan female body-place. In this essay, my interest is limited to Casey's interpretation of the Bachelardian place. In The Psychoanalysis of Fire and The Poetics of Space, Gaston Bachelard first argues for a psychological study of architecture. He invents "topoanalysis" and says it is an "auxiliary of psychoanalysis" (The Poetics of Space [Boston: Beacon P, 1994] 8). Casey uses Bachelard's method and suggests that place (for example, a childhood home) comes with the unconscious, full of "poetic images," and "poetic imagination." Place can be "imagined/remembered," "nonsensible," and "nonphysical and yet still count fully as place" (Fate 288). First, place is related to the "placial properties of certain images," and a person's "intimate being." A place-world produces an intimate space (290). Second, the intimate topoi can imply the "imagination of matter," provided that the imagination is "substantial enough to reside in," or "dense and intense enough for inhabitiation, real or imagined." Rooms or houses can be "dreamed, imagined, remembered - and read" (296, 291). Third, even though this imaginal place denotes an empty space, it may be well-structured, for everyone can envision a specific place with minute particulars. Finally, an imaginal place is associated with the "privileged status of the body." In Casey's words, "the house we reenter by means of images or words is itself bodylike." The doors and windows of a house can acquire "the physical and moral energy of a human body" (291).

4. Theodor W. Adorno and Max Horkheimer, Dialectic of Enlightenment (New York: Continuum, 1972) 43, xiv. They famously stated: "Myth is already enlightenment; and enlightenment reverts to mythology" (xvi).

5. In the words of Habermas, "mastery over nature is chained to the introjected violence of humans over humans, to the violence of the subject exercised upon its own nature." See Jürgen Habermas, Philosophical-Political Profiles (London: Heinemann, 1988) 101.

6. Joan Copjec, Read My Desire: Lacan against the Historicists (Cambridge: MIT P, 1994) 182. In tandem with Adorno and Horkheimer's picture, Juliet Flower MacCannell offers a somewhat Freudian account of the oedipal father in The Regime of the Brother: After the Patriarchy (New York: Routledge, 1991): the traditional oedipal figure ultimately repents from his rebellious act and re-identifies with the Law. He becomes a father via "a 'guilt' that is projected outward," thus he denies "himself relation to his family member" (16), and upholds the social contract that underlies the communal society. By "providing for sexual pairing and the perpetuation of the group" (14), the oedipal father becomes a superegoic "moral lawgiver" and establishes a patriarchy (17). The irony is that, having gone "through a castration that is the price of full citizenship in group life," the father promotes the "Oedipal symbolic" that "excuses abuses in its name," and welcomes a fantasmal order, a "logical contradiction in the final reduction of plurality again to the one" (20).

7. MacCannell 12-3.

8. James M. Mellard, “Lacan and New Lacanians, Josephine Hart’s Damage, Lacanian Tragedy, 
and the Ethics of Jouissance," PMLA 113.3 (May 1998): 396.

9. MacCannell 16.

10. Slavoj Žižek, Enjoy Your Symptom! Jacques Lacan in Hollywood and Out (New York: Routledge, 2001) 125.

11. Slavoj Žižek, Metastases of Enjoyment (London: Verso, 1994) 206.

12. Henrik Ibsen, The Master Builder 344. All references are to Eleven Plays by Henrik Ibsen, Intro. by H.L. Mencken (New York: Modern Library, 1935).

13. MacCannell 15, 10.

14. Žižek, Metastases of Enjoyment 206.

15. Ibsen, The Master Builder 295, 298.

16. 375,339 .

17. 309,339 .

18. Žižek, Metastases of Enjoyment 206.

19. Ibsen, The Master Builder 347.

20. Sigmund Freud, Totem and Taboo, SE:13, trans. James Strachey (London: Hogarth P, 1955) $89,88,86$.

21. In terms of fact, not only is Solness illogical, but also inaccurate. Thus James L. Calderwood pointed out the lack of "causal relation between the fire and Solness's sense of guilt", for the fire breaks out in the clothes closet, and not in the flawed chimney as he wished. However, Calderwood says Solness should feel guilty because "[a]11 that counts is imposing one's will and attaining one's desire." See James L. Calderwood, "The Master Builder and the Failure of Symbolic Success." Modern Drama 27.4 (1984): 623.

22. Ibsen, The Master Builder 295, 376.

23. 340 .

24. MacCannell 18.

25. Ibsen, The Master Builder 377, 377.

26. Freud, The Origins of Religion (Harmondsworth: Penguin, 1990) 54, 55.

27. Ibsen, The Master Builder 349.

28. $345,366.352$.

29. Jean Laplanche, New Foundations in Psychoanalysis (London: Blackwell, 1989) 103.

30. Ibsen, The Master Builder 318, 323.

31. As the jouissance of sexual perversion cannot easily be "integrated" into a person's normal universe, Žižek notes "there is always "a gulf separating" the self from such jouissance. The self is often left with this "ceaseless questioning" of his "existence qua enjoyment"- "am I really that?" See Slavoj Žižek, The Plague of Fantasies (London: Verso 1997) 49.

32. Ibsen, The Master Builder 351.

33. $350,351,369$.

34. See Heinz Politzer, Freud and Tragedy (Riverside: Ariadne P, 2006) 144.

35. MacCannell 28.

36. Ibsen, The Master Builder 348.

37. By "classical ethics of justice" I am referring to the Christian notion of distributive justice. In the Old Testament, God lays down the law to protect the weak and it says, "you are not to exploit the hired servant who is poor and destitute, whether he is one of your brothers or strangers who lives in your towns." (Deu. 24:14) In the New Testament, Jesus commands everyone to love the neighbor as the self. And St. Paul also says, "Masters, make sure that your slaves are given what is just and fair." (Col. 4:1) The rich should "do good, and be rich in good works" (1 Tim. 6:18).

38. Ibsen, The Master Builder 372.

39. Žižek The Plague of Fantasy 55.

40. Ibsen, The Master Builder 297, 345, emphasis original.

41. Žižek The Plague of Fantasy 45.

42. Ibsen, The Master Builder 295.

43. $304,366,307$.

44. 341,348 , emphasis added, 342 .

45. 352 .

46. Theipharis Constantine Theoharis, Ibsen's Drama: Right Action and Tragic Joy. (New

York: St Martin's P, 1996) 179.

47. Ibsen, The Master Builder 377, 366. 
48. The full quotation is: "The Master Builder is a dead man before the curtain rises: the breaking of his body to pieces in the last act by its fall from the tower is rather the impatient destruction of a ghost of whose delirious whisperings Nature is tired than of one who still counts among the living." George Bernard Shaw, "Down Among the Dead Men," Shaw and Ibsen, ed. J. L. Wisenthal (Toronto: U of Toronto P, 1979) 173.

49. Ibsen, The Master Builder 305, 348, 297.

50. 335,361 .

51. 619,361 .

52. The importance of a transitional object to humans is vividly illustrated in the comic Peanuts. Without his blanket, Linus simply cannot function properly. Donald Woods Winnicott, Playing and Reality (NY: Routledge, 1991) 25.

53. Ibsen, The Master Builder 363.

54. $330,361,360,364$.

55. 364,374 .

56. $306,299,302$.

57. 333,316 .

58. According to Freud, the perverse father can ruin the girl, for her unprepared sexual system sees the whole event as trauma, and her understanding cannot integrate what happens to her. As the girl "forgets" this accident by means of primal repression, she develops hysterical symptoms afterwards. See Freud, "Further Remarks on the Neuropsychoses of Defense," SE:3, trans. James Strachey (London: Hogarth P, 1962) 168-9.

59. Ibsen, The Master Builder 317, 350-1, 367.

60. William Archer, "Introduction," The Collected Works of Henrik Ibsen, Vol. X (London: Heinemann, 1912) x; James McFarlane, Ibsen and Meaning (Norwich: Novik P, 1989) 297.

61. Ibsen, The Master Builder 335, 367, 329, 325-379, 365.

62. In Read My Desire, Joan Copjec notes that the power of the femme fatale lies in her incessant demand, for the femme fatale is expressed by "her constant demand for more and more satisfaction. The more the hero devotes himself to procuring it for her, the more she delights in hoarding it. The contract thus binds the hero to a lethal relation, one that goes from bad to worse." In addition, "The femme fatale is an agent of (evil) fate: the moment she appears...the hero's fate is sealed, events take their inexorable course. As a rule,... in her face, the hero can read the foreboding of his future doom" (199). See also Žižek, Enjoy Your Symptom 169.

63. Žižek, The Plague of Fantasy 49.

64. MacCannell 26-7.

65. Žižek notes, "woman is not an external, active cause which lures man into a fall—she is just a consequence, a result, a materialization of man's fall" (Enjoy Your Symptom 154).

66. Ibsen, The Master Builder 323, 379, 357.

67. Inga-Stina Ewbank, "The Last Plays," The Cambridge Companion to Ibsen, ed. James McFarlane (Cambridge: Cambridge U P, 1994) 119.

68. Ibsen, The Master Builder 357.

69. 366,377 , emphasis added, 357 .

70. $368,369,357,369,383$.

71. David B. Morris, "Gothic Sublimity," New Literary History 16 (Winter 1985): 306.

72. Solness's death can be interpreted in these ways: (1) It can be the result of divine retributive justice; (2) It can be the result of moral self-punishment as his dizzy conscience makes him slip. (3) It can be the result of acrophobia. (4) It can mean a romantic fight, a heroic gesture to fight for the unsanctioned love affair. To his death, he can narcissistically play the role of being a hero in her fantasy; (5) It can be a cowardly flight: he flees from reality to project an imaginary union with his love; (6) It can be the result of an accident or conspiracy, that is, he dies due to Hilde's distracting waving of Dr. Herdal's white shawl. (7) It can also mean the consummation of the adulterous act. Many critics take this view. Kristen Shepherd-Barr sees the falling body of Solness like a phallus, which highlights the sexual union with his love. Thus the final scene marks "the sexual overtone of the phallic tower being erected and of Hilde's orgastic swooning at the climatic moment when Solness falls to his death." Ibsen and the Early Modernist Theatre (Westport: Greenwood P, 1997) 120.

73. Barbara Hooper, "Desiring Presence, Romancing the Real," Annals of the Association of American Geographers, 91:4 (Dec 2001): 703-715, 709. 
74. Ibsen, The Master Builder 377.

75. Casey 289. The process of implacement is simple: "Just as a place is animated by the lived bodies that are in it, a lived place animates these same bodies as they become implaced there" (242).

76. Space architecture is afraid of the void, thus Solness always wants to build more, have more women, and properties. In the words of Casey, "In philosophy the threat of atopia calls forth a veritable ontomania, an irrational desire to have, and to know as much determinate presence as possible; in short, put Being before Place. Whether the philosopher is Parmenides or Plato, Aristotle or Plotinus, Descartes or Spinoza, Hegel or Whitehead, the aim remains the same: to fill up, to populate the empty field with as much determinate Being as possible." Casey, Getting Back into Place: Toward a Renewed Understanding of the Place-World (Bloomington: Indiana UP, 1993) xi.

77. Casey, "Between Geography and Philosophy: What Does it Mean to be in the Place-World?" Annals of the Association of American Geographers 91.4 (Dec 2001): 683-9.

78. Thomas Brockelman, "Lost in Space? On the Virtues and Vices in Edward Casey's AntiModernism,” Humanitas XVI.1 (2003): 46-7.

79. Casey, "Between Geography and Philosophy" 688-9.

80. Casey, The Fate of Place 288. 